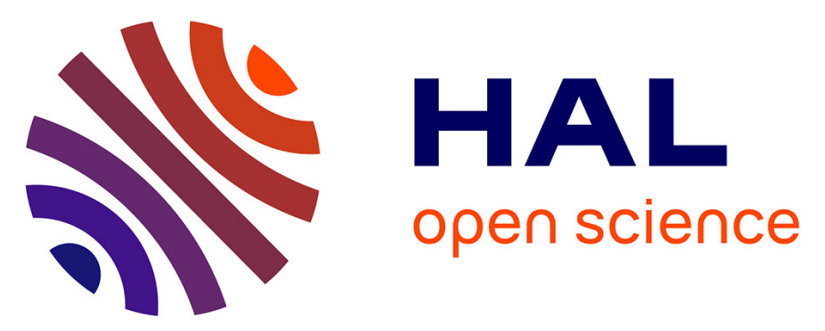

\title{
FoxO1 is not a key transcription factor in the regulation of myostatin (mstn-1a and mstn-1b) gene expression in trout myotubes
}

Iban Seiliez, Nathalie Sabin, Jean-Charles Gabillard

\section{- To cite this version:}

Iban Seiliez, Nathalie Sabin, Jean-Charles Gabillard. FoxO1 is not a key transcription factor in the regulation of myostatin (mstn-1a and mstn-1b) gene expression in trout myotubes. AJP - Regulatory, Integrative and Comparative Physiology, 2011, 301 (1), pp.R97-R104. 10.1152/ajpregu.00828.2010 . hal-01205025

\section{HAL Id: hal-01205025 \\ https://hal.science/hal-01205025}

Submitted on 29 May 2020

HAL is a multi-disciplinary open access archive for the deposit and dissemination of scientific research documents, whether they are published or not. The documents may come from teaching and research institutions in France or abroad, or from public or private research centers.
L'archive ouverte pluridisciplinaire HAL, est destinée au dépôt et à la diffusion de documents scientifiques de niveau recherche, publiés ou non, émanant des établissements d'enseignement et de recherche français ou étrangers, des laboratoires publics ou privés. 


\title{
FoxO1 is not a key transcription factor in the regulation of myostatin
}

\section{(mstn-la and mstn-1b) gene expression in trout myotubes}

\author{
Iban Seiliez, ${ }^{1 *}$ Nathalie Sabin, ${ }^{2}$ and Jean-Charles Gabillard ${ }^{2 *}$ \\ ${ }^{1}$ Institut National de la Recherche Agronomique, UMR 1067 Nutrition Aquaculture et Génomique, Pôle d'hydrobiologie, \\ St-Pée-sur-Nivelle; and ${ }^{2}$ Institut National de la Recherche Agronomique, UR 1037 Station Commune de Recherches en \\ Ichtyophysiologie, Biodiversité et Environnement, Equipe Croissance et Qualité de la Chair de Poisson, Campus de Beaulieu, \\ Rennes, France
}

Submitted 21 December 2010; accepted in final form 6 April 2011

Seiliez I, Sabin N, Gabillard JC. FoxO1 is not a key transcription factor in the regulation of myostatin (mstn-1a and mstn-1b) gene expression in trout myotubes. Am J Physiol Regul Integr Comp Physiol 301: R97-R104, 2011. First published April 13, 2011; doi:10.1152/ajpregu.00828.2010.-In mammals, much evidence has demonstrated the important role of myostatin (MSTN) in regulating muscle mass and identified the transcription factor forkhead box $\mathrm{O}$ (FoxO) 1 as a key regulator of its gene expression during atrophy. However, in trout, food deprivation leads to muscle atrophy without an increase of the expression of mstn genes in the muscle. We therefore studied the relationship between FoxO1 activity and the expression of both mstn genes ( $m s t n l a$ and $m s t n 1 b$ ) in primary culture of trout myotubes. To this aim, two complementary studies were undertaken. In the former, FoxO1 protein activity was modified with insulin-like growth factor-I (IGF-I) treatment, and the consequences on the expression of both mstn genes were monitored. In the second experiment, the expression of both studied genes was modified with growth hormone $(\mathrm{GH})$ treatment, and the activation of FoxO1 protein was investigated. We found that IGF-I induced the phosphorylation of FoxO1 and FoxO4. Moreover, under IGF-I stimulation, FoxO1 was no longer localized in the nucleus, indicating that this growth factor inhibited FoxO1 activity. However, IGF-I treatment had no effect on $m s t n 1 a$ and $m s t n 1 b$ expression, suggesting that FoxO1 would not regulate the expression of $m s t n$ genes in trout myotubes. Furthermore, the treatment of myotubes with GH decreased the expression of both mstn genes but has no effect on the phosphorylation of FoxO1, FoxO3, and FoxO4 nor on the nuclear translocation of FoxO1. Altogether, our results showed that mstnla and mstn $1 b$ expressions were not associated with FoxO activity, indicating that FoxO1 is likely not a key regulator of mstn genes in trout myotubes.

forkhead box O; myostatin; fish; muscle; atrophy; growth hormone; insulin-like growth factor-1

IN THE LAST DECADE, MYOSTATIN (MSTN), a member of the transforming growth factor- $\beta$ superfamily, has emerged as a key factor in muscle growth regulation (43). The importance of the mstn gene in muscle growth comes from the phenotype of MSTN-deficient cattle (natural mutation or deletion) called double-muscled bovines, like the Belgium Blue breed $(29,44)$. In these bovines, muscle overgrowth is due to both hyperplasia (increased number of muscle fibers) and hypertrophy (increased size of individual muscle fibers). Similarly, inactivation of the mstn gene or MSTN function is reported to cause

\footnotetext{
* I. Seiliez and J.-C. Gabillard contributed equally to this work.

Address for reprint requests and other correspondence: J.-C. Gabillard, INRA, UR1037 Station Commune de Recherches en Ichtyophysiologie Biodiversité et Environnement (SCRIBE), Equipe Croissance et Qualité de la Chair de Poisson, Campus de Beaulieu, 35000 Rennes, France (e-mail: Jean-Charles.Gabillard@ rennes.inra.fr).
}

increased muscle mass in a variety of species, including mice (Mus musculus) (43), dogs (Canis familiaris) (47), sheep (Ovis aries) (8), humans (Homo sapiens) (56), zebrafish (Danio rerio) (35), and trout $(36,45)$. Reversely, overexpression of MSTN in transgenic mice has been shown to induce muscle atrophy in vivo (50). These data demonstrate the predominant role of MSTN in regulating muscle size in both lower and higher vertebrates.

In agreement with its role as a negative regulator of skeletal muscle mass, expression data from a wide variety of mammalian models show that mstn is upregulated during muscle atrophy induced by hindlimb unloading (9), thermal injury (31), and food deprivation (2). However, other findings show some differences in the response of the mstn gene to environmental changes depending on the species or the conditions studied $(20,25,26,63)$. To make inroads in the understanding of mstn regulation, several groups investigate the regulatory elements controlling mstn expression. Conserved sequences in the mstn promoter from several species have thus been identified that share many binding sites for forkhead box $\mathrm{O}$ (FoxO) transcription factors $(3,4,13)$. Furthermore, some of these FoxO-binding sites were shown to be critical for FoxO1 binding and mstn gene expression $(3,4)$. FoxO1, which belongs to a subfamily of transcription factors consisting of FoxO1, FoxO3, FoxO4, and FoxO6 (39), is also known as the main coordinator of the two main proteolytic pathways (the ubiquitin proteasome and the autophagy lysosome) by inducing several autophagy-related genes as well as the two musclespecific ubiquitin ligases atrogin-1 and murf1 (40, 64). Nuclear localization and transcriptional activity of the FoxO transcription factors are inhibited via phosphorylation by the phosphatidylinositol 3-kinase (PI 3-kinase)/protein kinase B (Akt) signaling pathway, which in turn is activated by insulin-like growth factor-I (IGF-I) binding to its cell surface receptor (55, $61)$. Thus the regulation of FoxO function may play a central role in mediating effects on gene expression in response to atrophic and/or hypertrophic signaling.

In fish, less is known on the regulation of the expression of mstn genes (52). A recent phylogenetic analysis of the entire mstn subfamily (30) indicates that fish possess multiple mstn genes and that a gene duplication event during early fish radiation $(5,49)$ produced two distinct $m s t n$ clades: $m s t n-1$ and $m s t n-2$. A second duplication event within salmonids, likely resulting from tetraploidization, produced two subsequent divisions, one in each clade. This suggests that most, if not all, salmonids possess four distinct mstn genes: two within the first clade ( $1 \mathrm{a}$ and $1 \mathrm{~b}$ ) and two in the second ( $2 \mathrm{a}$ and $2 \mathrm{~b}$ ). In rainbow trout, from these four mstn genes only two (mstnla and 
$m s t n 1 b)$ are expressed in the muscle and are downregulated during starvation (28). In addition, they are differentially regulated under different conditions. Indeed, muscle atrophy during the reproductive stage is associated with a decrease of $m s t n 1 b$ expression, whereas mstnla expression is unaffected (51). Injection of growth hormone (GH) upregulates mstnla and downregulates $m s t n l b$ gene expression in muscle $(7,16)$. Overall, these data suggest that, in rainbow trout, regulation of mstn gene expression is complex and likely different from that observed in mammals.

Recent in vitro studies show that the hormonal (insulin and/or IGF-I) regulation of the Akt-FoxO signaling in rainbow trout is well conserved $(10,12,32,48,57,58)$. Furthermore, similarly to what is observed in mammalian and birds, this pathway has been shown to be associated with muscle atrophy in this species (59). However, we know little about the molecular mechanisms regulating the expression of the mstn genes in any fish species. The purpose of the present work was therefore to determine the role of FoxO1 in regulating the expression of the muscle antigrowth factors mstnla and mstn $1 b$ in rainbow trout. To establish a causal link between FoxO activity and the expression of both mstn genes, two complementary experiments were performed in primary cultures of trout muscle cells. In the former, FoxO1 protein activity was modified with IGF-I treatment, and the consequences on the expression of both $m s t n$ genes were monitored. In the second experiment, the expression of both studied genes was modified with GH treatment, and the activation of FoxO1 protein was investigated.

\section{MATERIALS AND METHODS}

Animals. Rainbow trout were maintained at the "Station Commune de Recherches en Ichtyophysiologie, Biodiversité et Environnement" (Rennes, France) in $0.6-\mathrm{m}^{3}$ tanks in a recirculated system at $18^{\circ} \mathrm{C}$. All experiments were carried out in accordance with legislation governing the ethical treatment of animals (Decret No. 2001-464, May 29, 2001), and investigators were certified by the French Government to carry out animal experiments (No. agrément 35-47). All animal work was approved by the Ministere de l'Enseignement Superieur et de le Recherche (Autorisation No. A352386).

Myosatellite cell isolation and culture. Primary cultures of skeletal muscle cells were carried out as follows: for each culture, 30-60 animals, each weighing $\sim 5 \mathrm{~g}$, were killed by a blow to the head and then immersed for $30 \mathrm{~s}$ in $70 \%$ ethanol to sterilize external surfaces. Cells were isolated, pooled, and cultured following previously described protocols $(15,58)$. Briefly, after removal of the skin, dorsal white muscle was isolated under sterile conditions and collected in Dulbecco's modified Eagle's medium (DMEM) containing $9 \mathrm{mM}$ $\mathrm{NaHCO}_{3}, 20 \mathrm{mM}$ HEPES, 15\% horse serum, and antibiotic-antimycotic cocktail (100 U/ml penicillin, $100 \mu \mathrm{g} / \mathrm{ml}$ streptomycin, and 0.25 $\mathrm{g} / \mathrm{ml}$ fungizone) at $\mathrm{pH}$ 7.4. After mechanical dissociation of the muscle in small pieces, the tissue was enzymatically digested with a $0.2 \%$ collagenase solution in DMEM for $1 \mathrm{~h}$ at $18^{\circ} \mathrm{C}$ and gentle shaking. The suspension was centrifuged $\left(300 \mathrm{~g}\right.$ for $5 \mathrm{~min}$ at $\left.15^{\circ} \mathrm{C}\right)$, and the resulting pellet was subjected to two rounds of enzymatic digestion with a $0.1 \%$ trypsin solution in DMEM for $20 \mathrm{~min}$ at $18^{\circ} \mathrm{C}$ with gentle agitation. After each round of trypsinization, the suspension was centrifuged, and the supernatant was diluted in two volumes of cold DMEM supplemented with $15 \%$ horse serum and the same antibiotic-antimycotic cocktail mentioned above. After two washes with DMEM, the cellular suspension was filtered through 100- and $40-\mu \mathrm{m}$ nylon filters. All experiments were conducted with cells seeded at a density of $160,000 / \mathrm{cm}^{2}$, in 6 -well or 24 -well plastic plates (Nunc, Roskilde, Denmark), and left for $30 \mathrm{~min}$ before medium change. Plates and cover slips were previously treated with poly-Llysine and laminin to facilitate satellite cell adhesion. Cells were incubated at $18^{\circ} \mathrm{C}$, the optimal temperature for culture, with DMEM (no. D7777; Sigma) containing $9 \mathrm{mM} \mathrm{NaHCO} 3,20 \mathrm{mM}$ HEPES, 10\% FBS, and antibiotic-antimycotic cocktail under an air atmosphere. The medium was renewed every 2 days, and observations of morphology were regularly made to control the state of the cells. They were cultured for 7 days to obtain myotubes.

Treatment conditions. The experiments of the present study were performed on myotubes that, compared with myoblasts, are closer to a myofiber and thus more relevant at a physiological point of view. On the day of the experiment, cells were deprived of serum for $24 \mathrm{~h}$ and subsequently incubated in the presence or absence of $100 \mathrm{nM}$ salmon/ trout IGF-I (WU100 GroPep) or 0.5 and $5 \mathrm{nM}$ of trout GH [homemade recombinant $\mathrm{GH}$ (34)] for $15 \mathrm{~min}, 30 \mathrm{~min}, 1 \mathrm{~h}, 2 \mathrm{~h}, 5 \mathrm{~h}$, or $24 \mathrm{~h}$. Each experiment was performed at least two times.

Gene expression analysis. Treatment medium was removed, and wells were washed two times with PBS. Total RNA was extracted with a Nucleospin RNA XS kit (no. N0740-902-50; MachereyNagel) according to the manufacturer's recommendations. The total amount of RNA was determined as a function of absorbance at 260 $\mathrm{nm}$ (Nanodrop ND-1000 spectrophotometer). cDNA was generated with $0.5 \mu \mathrm{g}$ total RNA using a commercial kit (no. 4368813; Applied Biosystems). Briefly, $0.5 \mu \mathrm{g}$ of total RNA was incubated in a $25-\mu \mathrm{l}$ mixture $(10 \times$ RT buffer, $25 \times \mathrm{dNTPs}, 10 \times$ random primers, $50 \mathrm{IU} / \mu \mathrm{l}$ MultiScribe Reverse Transcriptase, and nuclease-free water) at $25^{\circ} \mathrm{C}$ for $10 \mathrm{~min}$ and then at $37^{\circ} \mathrm{C}$ for $120 \mathrm{~min}$. The reaction was set at 200 $\mu \mathrm{l}$ by the addition of nuclease-free water. Target gene expression levels were determined by quantitative RT-PCR using a StepOnePlus system (Applied Biosystems). Analyses were carried out using a real-time PCR kit (fast SyberGreen Master mix, no. 4385612; Applied Biosystems) with $300 \mathrm{nM}$ of each primer. The primer sequences (Table 1) were already published and validated (28). Amplification was then performed using the following cycle: $95^{\circ} \mathrm{C}$ for $3 \mathrm{~s}$ and $60^{\circ} \mathrm{C}$ for $15 \mathrm{~s}, 40$ times for all primers. Real-time PCR data were normalized according to elongation factor $1 \alpha(\mathrm{EF} 1 \alpha) \mathrm{mRNA}$ abundance in each sample. Melting curves were systematically monitored (temperature gradient at $0.5^{\circ} \mathrm{C} / 10 \mathrm{~s}$ from 55 to $94^{\circ} \mathrm{C}$ ) at the end of the last amplification cycle to confirm the specificity of the amplification reaction. Each PCR run included replicate samples (duplicate of reverse transcription and PCR amplification) and negative controls (reverse transcriptase-free and RNA-free samples).

The relative expression ratio of a target gene was calculated on the basis of real-time PCR efficiency and the cycle threshold $\left(\mathrm{C}_{\mathrm{T}}\right)$ deviation $\left(\Delta \mathrm{C}_{\mathrm{T}}\right)$ of the unknown sample vs. a control sample and expressed compared with the EF1 $\alpha$ reference gene. PCR efficiency was measured by the slope of a standard curve using serial dilutions of cDNA. PCR efficiency values ranged between 1.9 and 2 .

Protein extraction and western blotting. After two washes with cold PBS, proteins were extracted with RIPA buffer (50 mM Tris, $\mathrm{pH}$ 8, $1 \mathrm{mM}$ EDTA, $0.5 \mathrm{mM}$ EGTA, $1 \%$ Nonidet P-40, $0.5 \%$ sodium deoxycholate, $0.1 \% \mathrm{SDS}$, and $150 \mathrm{mM} \mathrm{NaCl}$ ) supplemented with 5 $\mathrm{mM} \mathrm{NaF}, 1 \mathrm{mM} \mathrm{NaVO}$, and protease inhibitor cocktail (Roche). Laemmli buffer was added to the sample and heated at $90^{\circ} \mathrm{C}$ for $5 \mathrm{~min}$. Cell lysates were subjected to SDS-PAGE and Western blotting using

Table 1. Sequences of the primer pairs used for real-time quantitative $R T-P C R$

\begin{tabular}{lll}
\hline \hline \multicolumn{1}{c}{ Gene } & \multicolumn{1}{c}{ 5'-3' Forward Primer $^{\prime}$} & \multicolumn{1}{c}{ 5'-3' Reverse Primer } \\
\hline mstnla & CCGCCTTCACATATGCCAA & CAGAACCTGCGTCAGATGCA \\
mstn1b & AGTCCGCCTTCACGCAAA & ACCGAAAGCAACCATAAAACTCA \\
Atrogin-1 & TGCGATCAAATGGATTCAAA & GATTGCATCATTTCCCCACT \\
EFl $\alpha$ & TCCTCTTGGTCGTTTCGCTG & ACCCGAGGGACATCCTGTG \\
\hline
\end{tabular}

GenBank accession no.: myostatin (mstn) 1a, AF273035; mstn1b, AF273036; atrogin-1, CX026010; elongation factor $1 \alpha(E F 1 \alpha)$, AF498320. 
Table 2. Location and sequences of sites matching the consensus for FoxO binding ( $C / G$ A/T A A A C/T A) in mstnla and mstn1b promoters

\begin{tabular}{|c|c|}
\hline Location* & Sequence \\
\hline \multicolumn{2}{|c|}{ mstn1a } \\
\hline $\begin{array}{l}-837 \text { to }-843 \\
-862 \text { to }-868 \\
-1153 \text { to }-1159\end{array}$ & $\begin{array}{l}\text { gtaaata } \\
\text { ctaaata } \\
\text { gaaaata }\end{array}$ \\
\hline \multicolumn{2}{|c|}{ mstn1b } \\
\hline $\begin{array}{l}-793 \text { to }-799 \\
-883 \text { to }-889 \\
-1121 \text { to }-1127 \\
-1765 \text { to }-1771 \\
-2247 \text { to }-2253\end{array}$ & $\begin{array}{l}\text { gtaaata } \\
\text { gaaaata } \\
\text { gtaaata } \\
\text { ctaaata } \\
\text { gtaaata }\end{array}$ \\
\hline
\end{tabular}

*The table shows the location of the putative forkhead box O (FoxO)binding sites within the trout mstnla and mstn $1 b$ promoter sequences previously published by Garikipati et al. (17). Nos. represent the position of these elements relative to the transcription start site.

the appropriate antibody. Anti-phospho Akt ( $\left.\operatorname{Ser}^{473}\right)$ (no. 9271), anti-Akt (no. 9272), anti-phospho-FoxO1 $\left(\mathrm{Thr}^{24}\right) / \mathrm{FoxO} 3\left(\mathrm{Thr}^{32}\right)$ (no. 9464), and anti-phospho-FoxO1 ( $\left.\mathrm{Ser}^{319}\right) / \mathrm{FoxO} 4\left(\mathrm{Ser}^{262}\right)$ (no. 2487) were purchased from Cell Signaling Technologies (Ozyme, Saint Quentin Yvelines, France). Anti-FoxO1 (no. 1874-1) was purchased from Epitomics, and anti- $\beta$-actin (no. sc-47778) was from Santa Cruz Biotechnology. Anti-Akt, anti-phospho-Akt, anti-phospho-FoxO1 $\left(\mathrm{Thr}^{24}\right) /$ FoxO3 $\left(\mathrm{Thr}^{32}\right)$, and anti-phospho-FoxO1 $\left(\mathrm{Ser}^{319}\right) / \mathrm{FoxO} 4$ $\left(\mathrm{Ser}^{262}\right)$ antibodies have been previously validated in trout $(12,58)$. For anti-FoxO1 antibody, the amino acid sequences of FoxO1 were monitored in the SIGENAE database (60) to check for well-conservation of the antigen sequence. Next, preliminary Western blots with the anti-FoxO1 antibody were performed with lysates from the murine $\mathrm{C}_{2} \mathrm{C}_{12}$ cell line and from trout. With satellite cell lysate, we obtained a single band $\left(75 \mathrm{kDa}\right.$ ) with the same size as that of $\mathrm{C}_{2} \mathrm{C}_{12}$ (data not shown). After being washed, the membrane was incubated for $1 \mathrm{~h}$ with secondary antibody $(1: 15,000)$ linked to horseradish peroxidase (Jackson Immunoresearch). Immunoreactive bands were visualized by enhanced chemiluminescence, and images were obtained with an image acquisition system (Fusion FX7; Vilbert Lourmat).

Immunofluorescence analysis. Cells on glass cover slips were briefly washed two times by PBS and fixed for 10 min with $4 \%$ paraformaldehyde. For permeabilization, cells were incubated for 3 min in $0.1 \%$ Triton X-100/PBS. After three washes, cells were saturated for $1 \mathrm{~h}$ with $3 \%$ BSA and $0.1 \%$ Tween 20 in PBS (PBST). Cells were incubated for $3 \mathrm{~h}$ with the first antibody anti-FoxO1 (Cell Signaling Technologies) diluted in blocking buffer. The secondary antibody, anti-rabbit Alexa594 (Invitrogen), was diluted in PBST and applied for $1 \mathrm{~h}$. Cells were mounted with Mowiol 4-88 (no. 475904; Calbiochem) containing Hoescht $(0.5 \mu \mathrm{g} / \mathrm{ml})$. Cells were photographed using a Canon digital camera coupled to a Canon 90i microscope.

Statistical analysis. Data on gene expression analysis are expressed as means $\pm \mathrm{SD}(n=6)$ and were analyzed by one-way ANOVA followed by the Student-Newman-Keuls test. For all statistical analyses, the level of significance was set at $P<0.05$.

\section{RESULTS}

FoxO-binding sites are present in the promoter of both mstn genes. To assess the possibility that FoxO transcription factors could bind to the trout mstn promoters, we searched for the presence of putative binding sites for FoxO within the sequences previously published by Garikipati et al. (17). Sequence analysis based on a consensus sequence for FoxO- binding sites $([\mathrm{C} / \mathrm{G}][\mathrm{A} / \mathrm{T}] \mathrm{AAA}[\mathrm{C} / \mathrm{T}] \mathrm{A})$ derived from a previous study (21) identified the presence of three putative FoxObinding sites in the mstnla promoter and five in the mstn $1 b$ promoter (Table 2).

IGF-I inhibits FoxOl activity but has no effect on mstnla and mstnlb gene expression. To study the involvement of the Akt-FoxO signaling pathway in the regulation of mstnla and $m s t n 1 b$ gene expression, we first investigated the specific effect of IGF-I on the Akt-FoxO signaling pathway and the expression of both mstn genes in primary cultures of trout muscle cells. Trout cultured myotubes (day 7 of culture) were serumdeprived for $24 \mathrm{~h}$ to enhance the nonphosphorylated nuclear form of FoxO1 and subsequently incubated in the absence or presence of $100 \mathrm{nM}$ salmon IGF-I during different periods of time. As shown in Fig. 1, IGF-I stimulated the phosphorylation of Akt at Ser ${ }^{473}$, FoxO1 at Ser ${ }^{319}$, and Foxo4 at $\mathrm{Ser}^{262}$ as early as $15 \mathrm{~min}$ after treatment, and this stimulatory effect was observed for up to $5 \mathrm{~h}$.

We then monitored by immunofluorescence the localization of FoxO1 in serum-deprived cells for $24 \mathrm{~h}$ and incubated or not with $100 \mathrm{nM}$ of IGF-I for 1-5 h. As shown in Fig. 2, immunofluorescence of serum-starved cells (control) revealed that FoxO1 colocalizes with Hoescht staining, indicating a nuclear localization of the studied protein. In contrast, IGF-Itreated cells showed the loss of nuclear staining for FoxO1, indicating that IGF-I treatment prevents nuclear translocation of FoxO1.

To test the effect of IGF-I on mstnla and mstnlb gene expression, cells were then stimulated for $24 \mathrm{~h}$ with $100 \mathrm{nM}$ IGF-I. The expression of atrogin- 1 has been previously shown to be downregulated by IGF-I treatment of trout muscle cells $(12,58)$ and was therefore monitored as a control. As expected, atrogin- 1 was downregulated ( $\sim 2$-fold) after $24 \mathrm{~h}$ of stimulation with IGF-I (Fig. 3). In contrast, the hormonal treatment had no significant effect on either mstnla or mstnlb gene

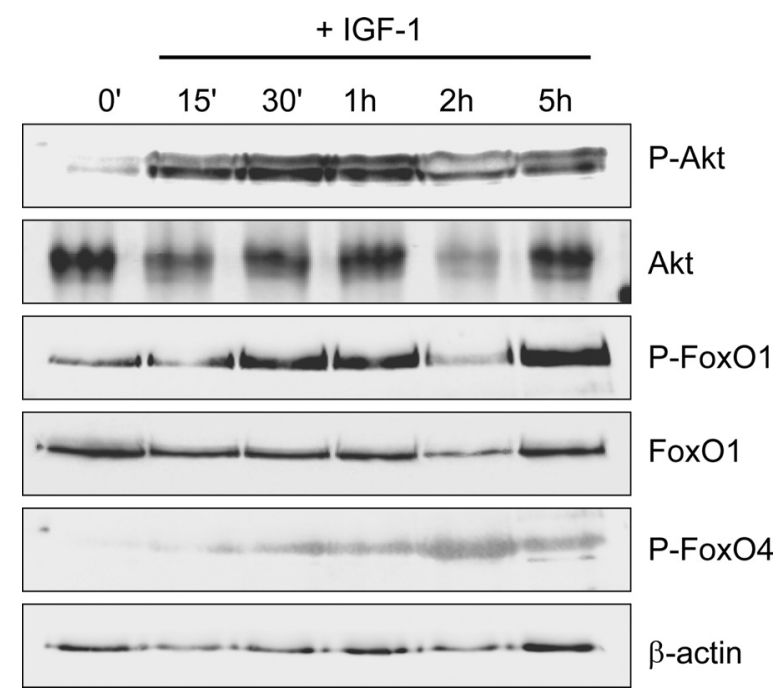

Fig. 1. Effect of insulin-like growth factor-I (IGF-I) on the protein kinase B (Akt)-forkhead box O (FoxO) signaling pathway in primary culture of trout muscle cells. Seven-day-old cells were serum starved for $24 \mathrm{~h}$ and then stimulated or not with $100 \mathrm{nM}$ of trout IGF-I for $15 \mathrm{~min}, 30 \mathrm{~min}, 1 \mathrm{~h}, 2 \mathrm{~h}$, or $5 \mathrm{~h}$ before harvest. Cell lysates were analyzed by Western blot with the indicated antibodies. $\beta$-Actin was used as a loading control. P, phosphorylated. Each treatment was performed in triplicate, and similar results were obtained. This figure shows a representative blot. 


\section{CTRL}
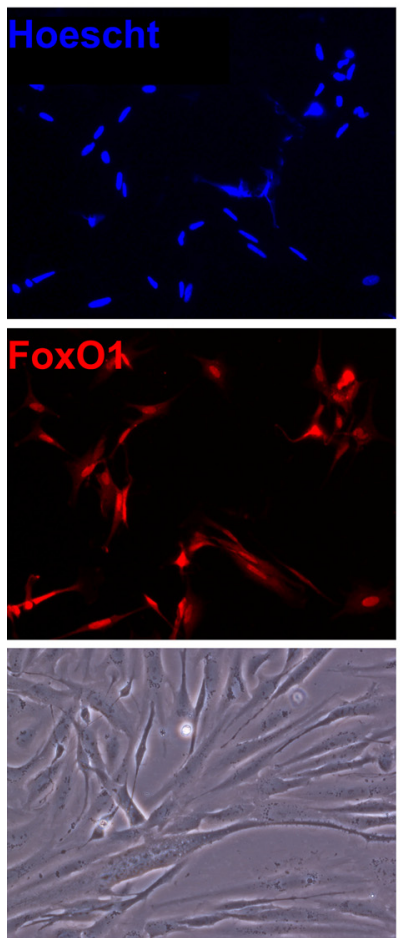

$1 \mathrm{~h}$
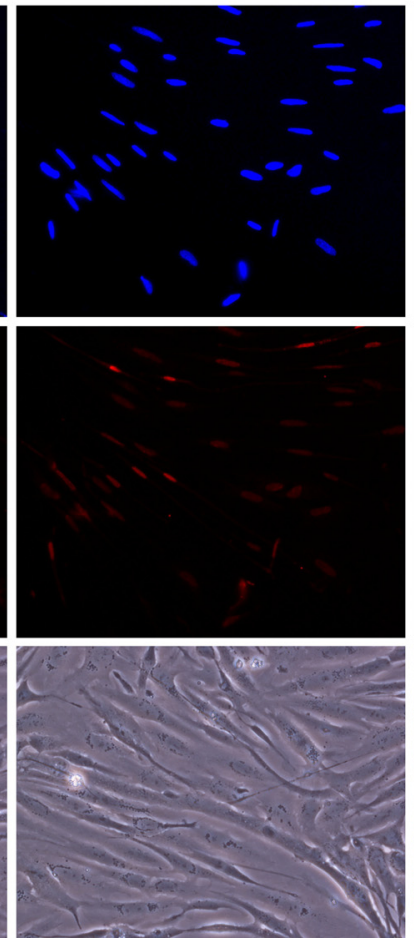

$3 h$
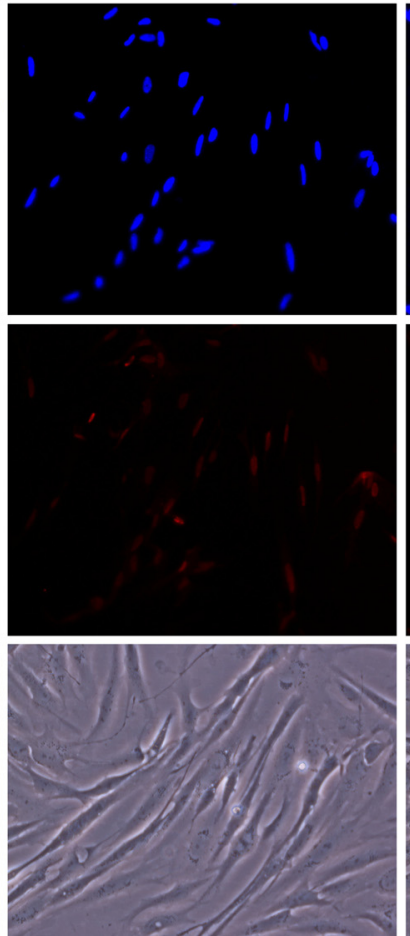

$5 h$
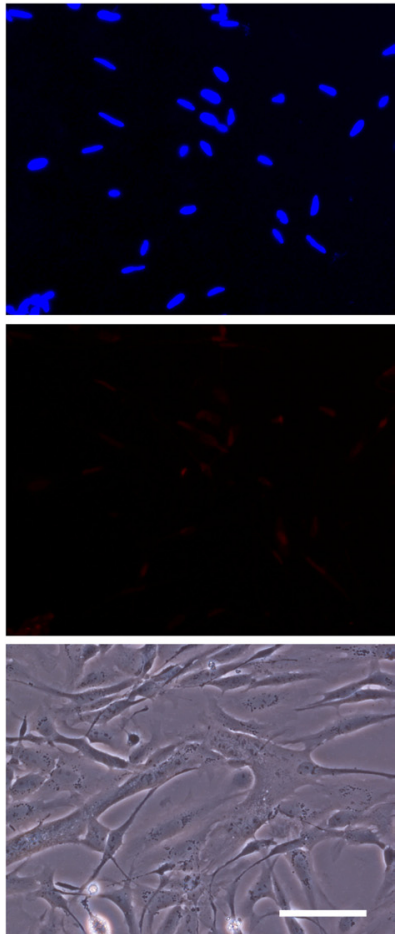

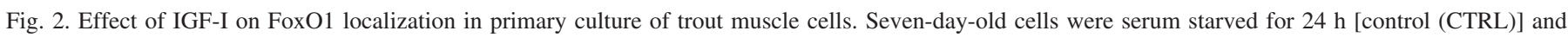

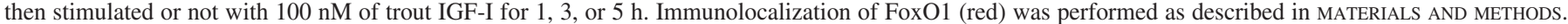
Nuclei were stained with Hoescht (blue). Bottom: representative bright-field images of control and IGF-I-treated myotubes. The scale represents $50 \mu m$.

expression. Overall, these results indicate that IGF-I inhibits FoxO1 activity without changing mstnla and mstnlb gene expression.

GH downregulates mstnla and mstn1b gene expression but has no effect on the Akt-FoxO signaling pathway. Another way to study the involvement of FoxO transcription factors in the regulation of mstnla and mstnlb gene expression was to analyze the Akt-FoxO signaling pathway in cells over- or underexpressing the studied genes. GH has been previously
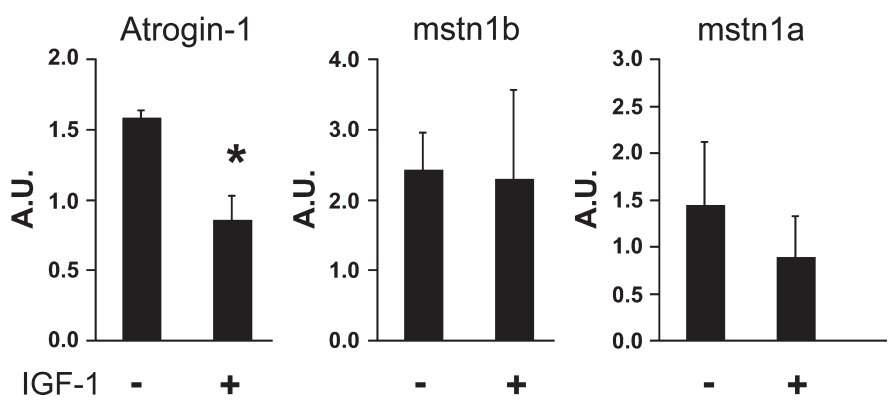

Fig. 3. Effect of IGF-I on the expression of atrogin-1, myostatin gene ( $m s t n$ ) $1 a$, and $m s t n l b$ in primary culture of trout muscle cells. Seven-day-old cells were serum starved for $24 \mathrm{~h}$ and then stimulated or not with $100 \mathrm{nM}$ of trout IGF-I for $24 \mathrm{~h}$ before harvest. Atrogin-1, mstnla, and mstn $1 b$ mRNA levels were estimated using real-time RT-PCR. For each treatment, six replicates were performed. Expression values [arbitrary units (AU)] were normalized with that of elongation factor $1 \alpha(\mathrm{EF} 1 \alpha)$ transcripts. Results are expressed as means $\pm \mathrm{SD}$ ( $n=6$ experiments). *Significant difference from the serumdeprived group $(P<0.05$, Student's $t$-test $)$. shown to regulate the expression of both mstnla and mstn $1 b$ in rainbow trout $(7,16)$. Therefore, we first investigated the effect of $\mathrm{GH}$ on mstnla and mstnlb gene expression in our cell culture model. Trout cultured myotubes (day 7 of culture) were serum-deprived for $24 \mathrm{~h}$ and subsequently incubated in the absence or presence of trout $\mathrm{GH}(0.5$ or $5 \mathrm{nM})$ for $24 \mathrm{~h}$. As shown in Fig. 4, both mstnla and mstn $1 b$ genes were downregulated ( $\sim 7$ - and 20 -fold, respectively) after $24 \mathrm{~h}$ of stimulation with $5 \mathrm{nM}$ of $\mathrm{GH}$. Thus these $\mathrm{GH}$-treated cells may serve as a relevant model to characterize the factors involved in the transcriptional regulation of mstn genes.

We then monitored the activity of the Akt-FoxO signaling pathway in these GH-treated cells. Previous studies had identified signal transducer and activator of transcription 5 (STAT5) as a key transcription factor in GH signaling (62), and we therefore monitored its phosphorylation status as a positive control. As expected, the phosphorylation of STAT5 was highly induced after $1 \mathrm{~h}$ of stimulation with GH (Fig. 5). In contrast, the hormonal treatment has no effect on the phosphorylation of Akt at $\mathrm{Ser}^{473}$, FoxO1 at $\mathrm{Ser}^{319}$, FoxO3 at $\mathrm{Thr}^{32}$, and FoxO4 at $\mathrm{Ser}^{262}$.

Finally, we monitored by immunofluorescence the localization of FoxO1 in serum-deprived cells for $24 \mathrm{~h}$ and incubated or not with $0.5 \mathrm{nM}$ of $\mathrm{GH}$ or $100 \mathrm{nM}$ of IGF-I for $1-5 \mathrm{~h}$. As shown in Fig. 6, immunofluorescence of serum-starved and GH-treated cells revealed that FoxO1 remained colocalized with Hoescht staining, indicating a nuclear localization of the studied protein. In contrast, IGF-I-treated cells showed a loss 

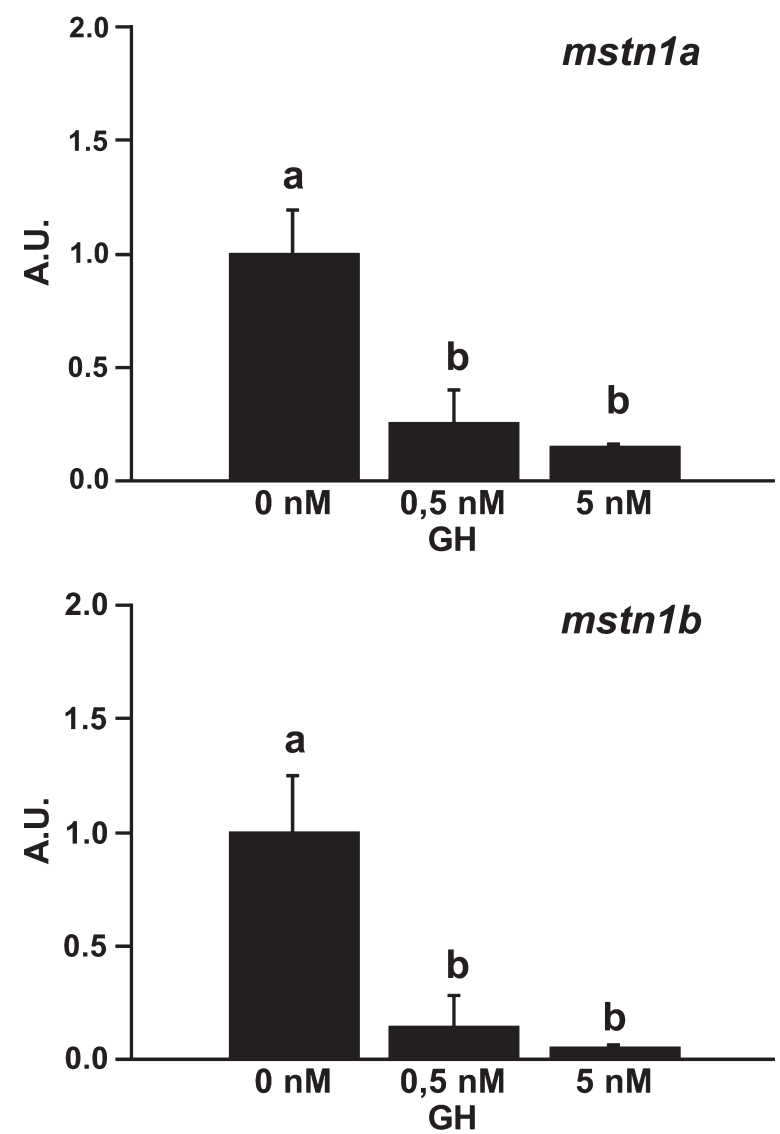

Fig. 4. Effect of growth hormone $(\mathrm{GH})$ on the expression of mstnla and $m s t n 1 b$ in primary culture of trout muscle cells. Seven-day-old cells were serum starved for $24 \mathrm{~h}$ and then stimulated or not with 0.5 or $5 \mathrm{nM}$ of trout $\mathrm{GH}$ for $24 \mathrm{~h}$ before harvest. mstn $1 a$ and $m s t n 1 b$ mRNA levels were estimated using real-time RT-PCR. For each treatment, six replicates were performed. Expression values $(\mathrm{AU})$ were normalized with that of EF1 $\alpha$ transcripts. Results are means $\pm \mathrm{SD}(n=6)$ and were analyzed using the one-way ANOVA followed by the Student-Newman-Keuls test for multiple comparisons. The different letters indicate significantly $(P<0.05)$ different means.

of nuclear localization of FoxO1. Taken together, these results show that GH downregulates mstnla and mstnlb gene expression in a FoxO-independent manner.

\section{DISCUSSION}

In mammals, there is accumulating evidence on the important role of the MSTN in regulating muscle mass and on the role of transcription factor FoxO1 as a key regulator of its gene expression in response to atrophic signaling $(3,4)$. In this regard, expression data from several mammalian models show that muscle atrophy is often associated with an increase of mstn expression $(2,9,31)$. However, in rainbow trout, food deprivation leads to muscle atrophy without an increase of msth expression in muscle $(11,28,46)$. Therefore, the purpose of the present work was to determine the role of FoxO1 in regulating the expression of the muscle antigrowth factors mstnla and $m s t n 1 b$ in rainbow trout.

To address this issue, we first conducted an in silico analysis aiming at identifying the presence of putative FoxO-binding sites within trout mstnla and mstnlb promoter sequences previously published (17). The very well conservation of the DNA-binding domain of FoxO proteins along the evolution (6) lets us hypothesize that the DNA sequence to which FoxO binds is the same between lower and higher vertebrates. Sequence analysis based on the consensus sequence for FoxObinding sites $([\mathrm{C} / \mathrm{G}][\mathrm{A} / \mathrm{T}] \mathrm{AAA}[\mathrm{C} / \mathrm{T}] \mathrm{A})$ derived from a previous study (21) identified the presence of several putative FoxO-binding sites in both trout msth promoters. This suggested the possible involvement of FoxO transcription factors on the control of mstnla and mstnlb expression.

In mammals, FOXO proteins are known to mediate the transcriptional output of insulin/IGF-I signal transduction (33, 61). When insulin/IGF-I signaling is active, a PI 3-kinase/Akt kinase cascade phosphorylates FOXO, leading to its nuclear exclusion. When insulin/IGF-I signaling is inhibited, unphosphorylated FOXO enters the nucleus where it induces the expression of several genes coding for key mediators of skeletal muscle atrophy, including mstn (reviewed in Ref. 18). We therefore investigated the effect of IGF-I on the Akt-FoxO signaling pathway and the expression of mstnla and mstn $1 b$ genes in our cell culture model. Our results showed that the treatment of cells with IGF-I enhanced the phosphorylation of Akt at $\mathrm{Ser}^{473}$, FoxO1 at $\mathrm{Ser}^{319}$, and Foxo4 at $\mathrm{Ser}^{262}$. Moreover, immunolocalization of FoxO1 clearly showed that IGF-I stimulation led to the loss of nuclear localization of FoxO1. The effect of IGF-I on the phosphorylation of Akt and FoxO1 in primary culture of trout muscle cells has already been reported $(10,12,58)$. The results presented here are in good agreement with these data and provide evidence for the first time that the effect of IGF-I is also accompanied by a nuclear exclusion of FoxO1 in this cell culture model, leading to the loss of FoxO1 staining. Indeed, Akt-mediated phosphorylation of FOXO leads to their proteasomal degradation through polyubiquitination by the E3 ubiquitin ligase $\operatorname{Skp} 2(24,42)$. In this study, we did not examine the effects of IGF-I on the nuclear translocation of other FoxO family members. However, according to data on mammals showing that both FoxO1 and FoxO3 are downstream targets of the insulin/IGF-I signaling (55), it is probable that IGF-I may have similar effects on the activation

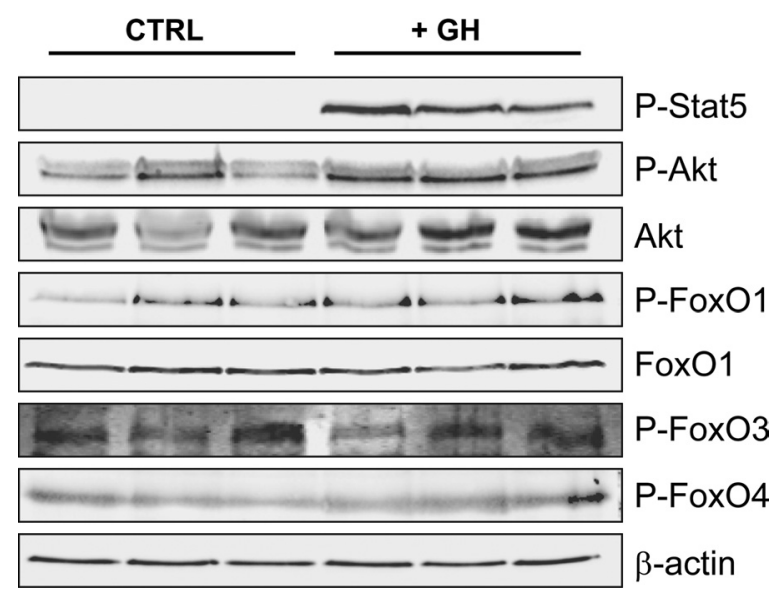

Fig. 5. Effect of GH on the Akt-FoxO signaling pathway in primary culture of trout muscle cells. Seven-day-old cells were serum starved for $24 \mathrm{~h}$ and then stimulated or not with $0.5 \mathrm{nM}$ of trout $\mathrm{GH}$ for $1 \mathrm{~h}$ before harvest. Cell lysates were analyzed by Western blot with the indicated antibodies. The phosphorylation of signal transducer and activator of transcription 5 (STAT5) was monitored as the positive control, and $\beta$-actin was used as the loading control. Each treatment was performed in triplicate, and similar results were obtained. This figure shows a representative blot. 


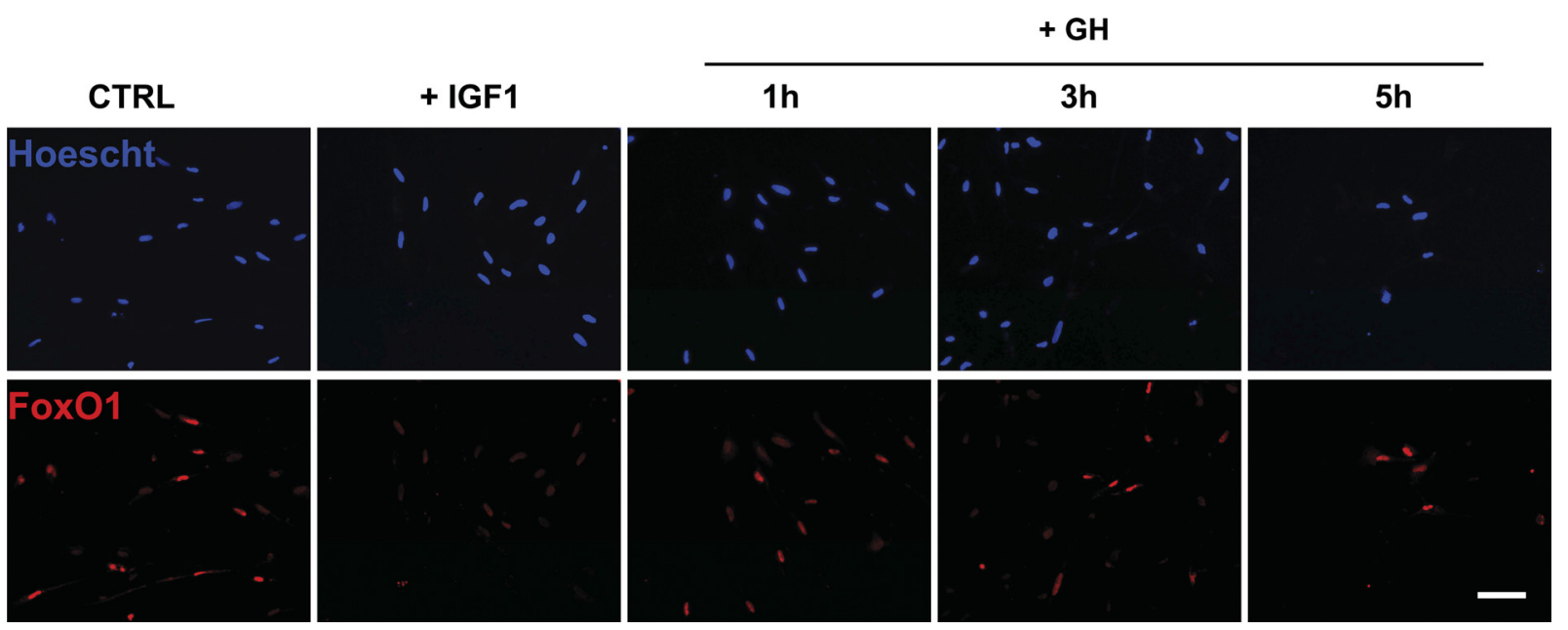

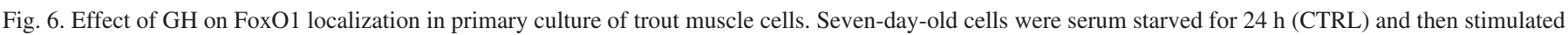

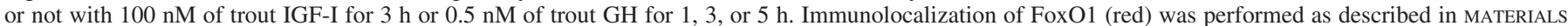
AND METHODS. Nuclei were stained with Hoescht (blue). The scale bar represents $50 \mu \mathrm{m}$.

of FoxO3 and other FoxO family members. In this regard, we recently showed that the treatment of primary culture of trout muscle cells with IGF-I enhances the phosphorylation of FoxO3 at $\mathrm{Thr}^{32}$ (58). To validate this decrease of FoxO activity, we then measured the expression of atrogin-1, a gene well-known to be dependent on FoxO activity $(55,61)$. As expected, IGF-I stimulation decreased the expression of atrogin- 1 in trout myotubes. This result confirmed that IGF-I stimulation induced a strong decrease of FoxO activity and thus validated our experimental conditions. However, under the same conditions, we were not able to observe any significant changes of mstnla and mstnlb gene expressions. Therefore, our results showed that, despite a strong decrease of FoxO1 activity, mstn gene expressions remained constant. These results suggest a slight role for the Akt-FoxO signaling pathway in the regulation of the expression of mstn genes in our cell culture model but do not exclude that other factors may mask the requirement of this intracellular pathway in the regulation of the studied genes. For example, new findings have provided direct evidence on the role of the transcription factors SMAD and CCAAT/enhancer-binding factor in mediating the induction of the expression of mstn gene in muscle wasting $(1,4)$. Whether some of these factors are affected in our cell culture model is worth investigating.

Another way to study the involvement of FoxO transcription factors in the regulation of mstn $1 a$ and $m \operatorname{stn} 1 b$ gene expression was to analyze the activation of the Akt-FoxO signaling pathway in cells over- or underexpressing the studied genes. GH has been previously shown to regulate the expression of msth in the muscle of human $(38)$ and rainbow trout $(7,16)$ as well as in the murine myoblast cell line $\mathrm{C}_{2} \mathrm{C}_{12}$ (38). The mechanism underlying $\mathrm{GH}$-mediated regulation of mstn expression is yet unknown. However, this effect could involve the Akt-FoxO signaling, as suggested by the induction of Akt phosphorylation in many cell systems stimulated by $\mathrm{GH}(22,27,54)$. Thus GH-stimulated cells may serve as a relevant model to study the involvement of FoxO1 in regulating the expression of the muscle antigrowth factors mstnla and mstnlb. Our in vitro results clearly showed that $\mathrm{GH}$ decreased the expression of both mstnla and mstn $1 b$ in trout myotubes. These results contrast with previous in vivo studies in trout showing that $\mathrm{GH}$ injection differentially regulates both $m s t n$ genes $(7,16)$, possibly reflecting inherent differences between cells in vivo and cells in culture. To gain insight on the involvement of AktFoxO signaling in the GH-mediated downregulation of both trout mstn genes in our in vitro model, we then monitored the activity of this signaling pathway in cells stimulated with $\mathrm{GH}$. Our Western blot analysis clearly showed that GH stimulation induced a strong phosphorylation of Stat5, known to be the major target of the cytokine signaling pathway (JAK/Stat) (23). However, under the same conditions, we did not observe any phosphorylation of Akt, FoxO1, FoxO3, and FoxO4. Moreover, FoxO1 protein remained in the nucleus after GH stimulation. Altogether, these results showed that $\mathrm{GH}$ did not change FoxO1 activity although GH strongly downregulated mstn $1 a$ and mastn $1 b$ expression in trout myotubes. In others words, the GH-induced decrease of $m s t n$ expression cannot be explained by a drop of FoxO1 activity in trout myotubes.

In this study, we clearly show that IGF-I inhibits FoxO1 activity without any changes of mstnla and mastn $1 b$ expressions and that GH stimulation strongly decreases mstn expressions without any changes in FoxO1 activity. Altogether, these results indicate that FoxO1 is not a key transcription factor in the regulation of the expression of both trout mstn genes in trout myotubes. In mammals, FoxO transcription factors are recognized to play a central role in the control of the expression of several genes coding for key mediators of skeletal muscle atrophy in response to atrophic and/or hypertrophic signaling (18). Therefore, the results presented here could be related to previous in vivo studies in trout showing no induction of the expression of either mstnla or mstnlb gene during muscle atrophy induced by starvation $(11,28,46)$. Furthermore, in tilapia (Oreochromis mossambicus), a decrease of mstn expression after food deprivation has even been observed (53), whereas, in zebrafish, mstn expression was shown to be independent of food restriction (41). In addition, during the reproduction period, trout undergoes muscle atrophy that is associated with a decrease of $m s t n 1 b$ expression (51). Altogether, these data show that the regulation of mstn gene in these fish species differs from that described in mammals and that the 
involvement of FoxO transcription factors in this process may account for a part in this difference. Furthermore, they indicate that, although the antigrowth properties of MSTN seem to be conserved throughout evolution $(19,37)$, the regulation of the mstn gene has dramatically evolved and remains to be explored in lower vertebrates.

\section{Perspectives and Significance}

The highly homologous sequences of MSTN protein's $\mathrm{COOH}$-terminal active region among species ranging from zebrafish to humans suggested that the functions of MSTN were extremely conserved throughout evolution $(17,19,37)$. However, there were higher differences for the promoter region among animals compared with the coding region $(14,17$, 19), resulting in some interspecies differences in the response of $m s t h$ gene to environmental changes $(7,16,20,26,51,53$, 63). The search for regulatory factors of $m s t n$ gene expression in different (model or livestock) species would therefore help the understanding of its function in the regulation of muscle mass. In this regard, rainbow trout is a very interesting model because of its two mstn genes differentially regulated in several environmental conditions. The present data indicate that FoxO1 activity is not a determining factor in the regulation of the expression of both mstnla and mstnlb genes in primary culture of trout myotubes. Further studies are warranted to follow these specific genes as affected by nutritional and hormonal factors.

\section{ACKNOWLEDGMENTS}

We thank F. Terrier, Y. Hontang, and F. Sandres for fish rearing in the INRA experimental farm (Donzacq, France) and Cécile Melin, Jean-Luc Thomas, and Frédéric Borel for fish maintenance at the "Station Commune de Recherches en Ichtyophysiologie, Biodiversité et Environnement" (SCRIBE, Rennes, France).

\section{GRANTS}

This study was supported by the French National Research Agency (ANR08-BLAN-0267 “MYOTROPHY”).

\section{DISCLOSURES}

No conflicts of interest are declared by the authors.

\section{REFERENCES}

1. Allen DL, Cleary AS, Hanson AM, Lindsay SF, Reed JM. CCAAT/ enhancer binding factor- $\Delta$ expression is increased in fast skeletal muscle by food deprivation and regulates myostatin transcription in vitro. Am J Physiol Regul Integr Comp Physiol 299: R1592-R1601, 2010.

2. Allen DL, Cleary AS, Lindsay SF, Loh AS, Reed JM. Myostatin expression is increased by food deprivation in a muscle-specific manner and contributes to muscle atrophy during prolonged food deprivation in mice. J Appl Physiol 109: 692-701, 2010.

3. Allen DL, Du M. Comparative functional analysis of the cow and mouse myostatin genes reveals novel regulatory elements in their upstream promoter regions. Comp Biochem Physiol B Biochem Mol Biol 150: 432-439, 2008.

4. Allen DL, Unterman TG. Regulation of myostatin expression and myoblast differentiation by FoxO and SMAD transcription factors. Am J Physiol Cell Physiol 292: C188-C199, 2007.

5. Amores A, Force A, Yan YL, Joly L, Amemiya C, Fritz A, Ho RK, Langeland J, Prince V, Wang YL, Westerfield M, Ekker M, Postlethwait JH. Zebrafish hox clusters and vertebrate genome evolution. Science 282: 1711-1714, 1998.

6. Anderson MJ, Viars CS, Czekay S, Cavenee WK, Arden KC. Cloning and Characterization of Three Human Forkhead Genes That Comprise an FKHR-like Gene Subfamily. Genomics 47: 187-199, 1998.
7. Biga PR, Cain KD, Hardy RW, Schelling GT, Overturf K, Roberts SB, Goetz FW, Ott TL. Growth hormone differentially regulates muscle myostatin1 and -2 and increases circulating cortisol in rainbow trout (Oncorhynchus mykiss). Gen Comp Endocrinol 138: 32-41, 2004.

8. Boman IA, Klemetsdal G, Blichfeldt T, Nafstad O, Vage DI. A frameshift mutation in the coding region of the myostatin gene (MSTN) affects carcass conformation and fatness in Norwegian White Sheep (Ovis aries). Anim Genet 40: 418-422, 2009.

9. Carlson CJ, Booth FW, Gordon SE. Skeletal muscle myostatin mRNA expression is fiber-type specific and increases during hindlimb unloading. Am J Physiol Regul Integr Comp Physiol 277: R601-R606, 1999.

10. Castillo J, Ammendrup-Johnsen I, Codina M, Navarro I, Gutierrez J. IGF-I and insulin receptor signal transduction in trout muscle cells. Am J Physiol Regul Integr Comp Physiol 290: R1683-R1690, 2006.

11. Chauvigne F, Gabillard JC, Weil C, Rescan PY. Effect of refeeding on IGFI, IGFII, IGF receptors, FGF2, FGF6, and myostatin mRNA expression in rainbow trout myotomal muscle. Gen Comp Endocrinol 132: 209-215, 2003.

12. Cleveland BM, Weber GM. Effects of insulin-like growth factor-I, insulin, and leucine on protein turnover and ubiquitin ligase expression in rainbow trout primary myocytes. Am J Physiol Regul Integr Comp Physiol 298: R341-R350, 2010.

13. Dall'Olio S, Fontanesi L, Nanni Costa L, Tassinari M, Minieri L, Falaschini A. Analysis of horse myostatin gene and identification of single nucleotide polymorphisms in breeds of different morphological types. J Biomed Biotechnol In press.

14. Du R, Chen YF, An XR, Yang XY, Ma Y, Zhang L, Yuan XL, Chen LM, Qin J. Cloning and sequence analysis of myostatin promoter in sheep. DNA Seq 16: 412-417, 2005.

15. Gabillard JC, Sabin N, Paboeuf G. In vitro characterization of proliferation and differentiation of trout satellite cells. Cell Tissue Res 342: 471-477, 2010.

16. Gahr SA, Vallejo RL, Weber GM, Shepherd BS, Silverstein JT, Rexroad CE 3rd. Effects of short-term growth hormone treatment on liver and muscle transcriptomes in rainbow trout (Oncorhynchus mykiss). Physiol Genomics 32: 380-392, 2008.

17. Garikipati DK, Gahr SA, Rodgers BD. Identification, characterization, and quantitative expression analysis of rainbow trout myostatin-1a and myostatin-1b genes. J Endocrinol 190: 879-888, 2006.

18. Glass DJ. Signaling pathways perturbing muscle mass. Curr Opin Clin Nutr Metab Care 13: 225-229, 2010.

19. Gu Z, Zhang Y, Shi P, Zhang YP, Zhu D, Li H. Comparison of avian myostatin genes. Anim Genet 35: 470-472, 2004.

20. Guernec A, Berri C, Chevalier B, Wacrenier-Cere N, Le Bihan-Duval E, Duclos MJ. Muscle development, insulin-like growth factor-I and myostatin mRNA levels in chickens selected for increased breast muscle yield. Growth Horm IGF Res 13: 8-18, 2003.

21. Guo S, Rena G, Cichy S, He X, Cohen P, Unterman T. Phosphorylation of serine 256 by protein kinase B disrupts transactivation by FKHR and mediates effects of insulin on insulin-like growth factor-binding protein-1 promoter activity through a conserved insulin response sequence. $J$ Biol Chem 274: 17184-17192, 1999.

22. Hayashi AA, Proud CG. The rapid activation of protein synthesis by growth hormone requires signaling through mTOR. Am J Physiol Endocrinol Metab 292: E1647-E1655, 2007.

23. Herrington J, Carter-Su C. Signaling pathways activated by the growth hormone receptor. Trends Endocrinol Metab 12: 252-257, 2001.

24. Huang H, Regan KM, Wang F, Wang D, Smith DI, van Deursen JM, Tindall DJ. Skp2 inhibits FOXO1 in tumor suppression through ubiquitin-mediated degradation. Proc Natl Acad Sci USA 102: 1649-1654, 2005.

25. Jeanplong F, Bass JJ, Smith HK, Kirk SP, Kambadur R, Sharma M, Oldham JM. Prolonged underfeeding of sheep increases myostatin and myogenic regulatory factor Myf-5 in skeletal muscle while IGF-I and myogenin are repressed. J Endocrinol 176: 425-437, 2003.

26. Ji S, Losinski RL, Cornelius SG, Frank GR, Willis GM, Gerrard DE, Depreux FF, Spurlock ME. Myostatin expression in porcine tissues: tissue specificity and developmental and postnatal regulation. Am J Physiol Regul Integr Comp Physiol 275: R1265-R1273, 1998.

27. Jin H, Lanning NJ, Carter-Su C. JAK2, but not Src family kinases, is required for STAT, ERK, and Akt signaling in response to growth hormone in preadipocytes and hepatoma cells. Mol Endocrinol 22: 18251841, 2008.

28. Johansen KA, Overturf K. Alterations in expression of genes associated with muscle metabolism and growth during nutritional restriction and 
refeeding in rainbow trout. Comp Biochem Physiol B Biochem Mol Biol 144: 119-127, 2006.

29. Kambadur R, Sharma M, Smith TP, Bass JJ. Mutations in myostatin (GDF8) in double-muscled Belgian Blue and Piedmontese cattle. Genome Res 7: 910-916, 1997.

30. Kerr T, Roalson EH, Rodgers BD. Phylogenetic analysis of the myostatin gene sub-family and the differential expression of a novel member in zebrafish. Evol Dev 7: 390-400, 2005.

31. Lang CH, Silvis C, Nystrom G, Frost RA. Regulation of myostatin by glucocorticoids after thermal injury. FASEB $J$ 15: 1807-1809, 2001.

32. Lansard M, Panserat S, Plagnes-Juan E, Seiliez I, Skiba-Cassy S. Integration of insulin and amino acid signals that regulate hepatic metabolism-related gene expression in rainbow trout: role of TOR. Amino Acids 39: 801-810, 2010.

33. Latres E, Amini AR, Amini AA, Griffiths J, Martin FJ, Wei Y, Lin HC, Yancopoulos GD, Glass DJ. Insulin-like growth factor-1 (IGF-1) inversely regulates atrophy-induced genes via the phosphatidylinositol 3-kinase/Akt/mammalian target of rapamycin (PI3K/Akt/mTOR) pathway. J Biol Chem 280: 2737-2744, 2005.

34. Le Bail PY, Sumpter JP, Carragher JF, Mourot B, Niu PD, Weil C. Development and validation of a highly sensitive radioimmunoassay for chinook salmon (Oncorhynchus tshawytscha) growth hormone. Gen Comp Endocrinol 83: 75-85, 1991.

35. Lee CY, Hu SY, Gong HY, Chen MH, Lu JK, Wu JL. Suppression of myostatin with vector-based RNA interference causes a double-muscle effect in transgenic zebrafish. Biochem Biophys Res Commun 387: $766-$ 771, 2009.

36. Lee SB, Kim YS, Oh MY, Jeong Ih Seong KB, Jin HJ. Improving rainbow trout (Oncorhynchus mykiss) growth by treatment with a fish (Paralichthys olivaceus) myostatin prodomain expressed in soluble forms in E. coli. Aquaculture 302: 270-278, 2010.

37. Lee SJ, McPherron AC. Regulation of myostatin activity and muscle growth. Proc Natl Acad Sci USA 98: 9306-9311, 2001.

38. Liu W, Thomas SG, Asa SL, Gonzalez-Cadavid N, Bhasin S, Ezzat S. Myostatin is a skeletal muscle target of growth hormone anabolic action. $J$ Clin Endocrinol Metab 88: 5490-5496, 2003.

39. Maiese K, Chong ZZ, Shang YC, Hou J. A "FOXO" in sight: targeting Foxo proteins from conception to cancer. Med Res Rev 29: 395-418, 2009.

40. Mammucari C, Milan G, Romanello V, Masiero E, Rudolf R, Del Piccolo P, Burden SJ, Di Lisi R, Sandri C, Zhao J, Goldberg AL, Schiaffino S, Sandri M. FoxO3 controls autophagy in skeletal muscle in vivo. Cell Metab 6: 458-471, 2007.

41. Masuda Y, Oku H, Okumura T, Nomura K, Kurokawa T. Feeding restriction alters expression of some ATP related genes more sensitively than the RNA/DNA ratio in zebrafish, Danio rerio. Comp Biochem Physiol B Biochem Mol Biol 152: 287-291, 2009.

42. Matsuzaki H, Daitoku H, Hatta M, Tanaka K, Fukamizu A. Insulininduced phosphorylation of FKHR (Foxo1) targets to proteasomal degradation. Proc Natl Acad Sci USA 100: 11285-11290, 2003.

43. McPherron AC, Lawler AM, Lee SJ. Regulation of skeletal muscle mass in mice by a new TGF-beta superfamily member. Nature 387 : 83-90, 1997.

44. McPherron AC, Lee SJ. Double muscling in cattle due to mutations in the myostatin gene. Proc Natl Acad Sci USA 94: 12457-12461, 1997.

45. Medeiros EF, Phelps MP, Fuentes FD, Bradley TM. Overexpression of follistatin in trout stimulates increased muscling. Am J Physiol Regul Integr Comp Physiol 297: R235-R242, 2009.

46. Montserrat N, Gabillard JC, Capilla E, Navarro MI, Gutierrez J. Role of insulin, insulin-like growth factors, and muscle regulatory factors in the compensatory growth of the trout (Oncorhynchus mykiss). Gen Comp Endocrinol 150: 462-472, 2007.

47. Mosher DS, Quignon P, Bustamante CD, Sutter NB, Mellersh CS, Parker HG, Ostrander EA. A mutation in the myostatin gene increases muscle mass and enhances racing performance in heterozygote dogs. PLoS Genet 3: e79, 2007.
48. Plagnes-Juan E, Lansard M, Seiliez I, Medale F, Corraze G, Kaushik S, Panserat S, Skiba-Cassy S. Insulin regulates the expression of several metabolism-related genes in the liver and primary hepatocytes of rainbow trout (Oncorhynchus mykiss). J Exp Biol 211: 2510-2518, 2008.

49. Postlethwait JH, Yan YL, Gates MA, Horne S, Amores A, Brownlie A, Donovan A, Egan ES, Force A, Gong Z, Goutel C, Fritz A, Kelsh R, Knapik E, Liao E, Paw B, Ransom D, Singer A, Thomson M, Abduljabbar TS, Yelick P, Beier D, Joly JS, Larhammar D, Rosa F, Westerfield M, Zon LI, Johnson SL, Talbot WS. Vertebrate genome evolution and the zebrafish gene map. Nat Genet 18: 345-349, 1998.

50. Reisz-Porszasz S, Bhasin S, Artaza JN, Shen R, Sinha-Hikim I, Hogue A, Fielder TJ, Gonzalez-Cadavid NF. Lower skeletal muscle mass in male transgenic mice with muscle-specific overexpression of myostatin. Am J Physiol Endocrinol Metab 285: E876-E888, 2003.

51. Rescan PY, Jutel I, Ralliere C. Two myostatin genes are differentially expressed in myotomal muscles of the trout (Oncorhynchus mykiss). $J$ Exp Biol 204: 3523-3529, 2001.

52. Rodgers BD, Garikipati DK. Clinical, agricultural, and evolutionary biology of myostatin: a comparative review. Endocr Rev 29: 513-534, 2008.

53. Rodgers BD, Weber GM, Kelley KM, Levine MA. Prolonged fasting and cortisol reduce myostatin mRNA levels in tilapia larvae; short-term fasting elevates. Am J Physiol Regul Integr Comp Physiol 284: R1277R1286, 2003.

54. Sadowski CL, Wheeler TT, Wang LH, Sadowski HB. GH regulation of IGF-I and suppressor of cytokine signaling gene expression in $\mathrm{C} 2 \mathrm{C} 12$ skeletal muscle cells. Endocrinology 142: 3890-3900, 2001.

55. Sandri M, Sandri C, Gilbert A, Skurk C, Calabria E, Picard A, Walsh K, Schiaffino S, Lecker SH, Goldberg AL. Foxo transcription factors induce the atrophy-related ubiquitin ligase atrogin- 1 and cause skeletal muscle atrophy. Cell 117: 399-412, 2004.

56. Schuelke M, Wagner KR, Stolz LE, Hubner C, Riebel T, Komen W, Braun T, Tobin JF, Lee SJ. Myostatin mutation associated with gross muscle hypertrophy in a child. N Engl J Med 350: 2682-2688, 2004.

57. Seiliez I, Gabillard JC, Skiba-Cassy S, Garcia-Serrana D, Gutierrez J, Kaushik S, Panserat S, Tesseraud S. An in vivo and in vitro assessment of TOR signaling cascade in rainbow trout (Oncorhynchus mykiss). Am J Physiol Regul Integr Comp Physiol 295: R329-R335, 2008.

58. Seiliez I, Gutierrez J, Salmeron C, Skiba-Cassy S, Chauvin C, Dias K, Kaushik S, Tesseraud S, Panserat S. An in vivo and in vitro assessment of autophagy-related gene expression in muscle of rainbow trout $(\mathrm{On}$ corhynchus mykiss). Comp Biochem Physiol B Biochem Mol Biol 157: 258-266, 2010.

59. Seiliez I, Panserat S, Skiba-Cassy S, Fricot A, Vachot C, Kaushik S, Tesseraud S. Feeding status regulates the polyubiquitination step of the ubiquitinproteasome-dependent proteolysis in rainbow trout (Oncorhynchus mykiss) muscle. J Nutr 138: 487-491, 2008.

60. SIGENAE. Information System of Breeding Animals' Genome. http:// www.sigenae. org/.

61. Stitt TN, Drujan D, Clarke BA, Panaro F, Timofeyva Y, Kline WO, Gonzalez M, Yancopoulos GD, Glass DJ. The IGF-1/PI3K/Akt pathway prevents expression of muscle atrophy-induced ubiquitin ligases by inhibiting FOXO transcription factors. Mol Cell 14: 395-403, 2004.

62. Waters MJ, Hoang HN, Fairlie DP, Pelekanos RA, Brown RJ. New insights into growth hormone action. J Mol Endocrinol 36: 1-7, 2006.

63. Yamaguchi A, Fujikawa T, Tateoka M, Soya H, Sakuma K, Sugiura T, Morita I, Ikeda Y, Hirai T. The expression of IGF-I and myostatin mRNAs in skeletal muscle of hypophysectomized and underfed rats during postnatal growth. Acta Physiol (Oxf) 186: 291-300, 2006.

64. Zhao J, Brault JJ, Schild A, Cao P, Sandri M, Schiaffino S, Lecker SH, Goldberg AL. FoxO3 coordinately activates protein degradation by the autophagic/lysosomal and proteasomal pathways in atrophying muscle cells. Cell Metab 6: 472-483, 2007. 